\title{
OPTIMALIZATION OF LEGAL PROTECTION FOR FEMALE HOUSEMAIDS IN INDONESIA
}

\author{
Marzellina Hardiyanti, Ani Purwanti \\ Faculty of Law, Diponegoro University \\ marzellina313@gmail.com \\ ani_purwanti81@yahoo.com
}

\begin{abstract}
Housemaids are one of the most vulnerable groups to violence and unfair wage. The problem is that, in Indonesia, female comprised $90 \%$ of the housemaids, thus making them even more vulnerable. Several cases of physical, psychological, and sexual violence that happened against housemaids are due to discriminative environment. This problem is what urges for the access of justice for female housemaids in Indonesia, thus the focus of this article. The research of this article used the normative legal approach based on literature studies and descriptive analysis towards the problem. The urgency of legal protection for female housemaids in Indonesia is caused by the prevalence of domestic violence and unfair compensation. Therefore, a comprehensive and exhaustive legal framework is needed to provide a sufficient access of justice mechanism for female housemaids, such as a legislative act specified for them. Rehabilitation is also a vital mechanism, especially to housemaids who suffered from violence by providing them temporary shelters, counseling, and protection from retalitation.
\end{abstract}

Keywords: Legal Protection; Female Housemaids; Indonesia

\section{Introduction}

Indonesia as a welfare state as in the concept of State Administration Law is a welfare state, where the state has the duty to work for the welfare of its people from various aspects of life both social, economic, political, legal, and cultural. The constitutional basis of the regulation that the State of Indonesia is a welfare state is contained in one of the objectives of the State of Indonesia, namely to advance public welfare in the Fourth Paragraph of the Preamble of the 1945 Constitution of the Republic of Indonesia.

The economic aspect becomes the main orientation in achieving everyone's welfare. To achieve an adequate level of economy, everyone strives to make various efforts to meet their personal needs as well as the needs of their families, one of which is by "doing work". Administrative law develops on the basis of economic development which also creates a variety of new problems including environmental, labor and planning issues.

Indonesia recognized about the concept of humanism. It has been contained in the second moral principle of Pancasila as "Kemanusiaan yang adil dan Beradab (Just and Civilized Humanity)". So, the basic ideology of the nation and its constitutions has formulated the 
concepts regarding appreciating human rights equally for men and women before the law. ${ }^{1}$ The efforts of the state to provide guarantees to citizens related to the fulfillment of the right to obtain work are regulated constitutionally in Article 27 Paragraph (2) of the 1945 Constitution of the Republic of Indonesia which states that every citizen has the right to obtain decent work and livelihood. On this basis then gave birth to the juridical basis of Law No. 13 of 2003 concerning Manpower in Indonesia. However, in reality employment in Indonesia still has problems, especially in terms of efforts to protect labor alignments.

Labour or can be called workers have constitutional rights that must be fulfilled by the state. This arrangement has actually been accommodated in Law No. 13 of 2003 concerning Manpower, but the understanding of the community, especially employers, employers and the government still considers in the regulation the rights of workers in both the formal and informal sectors have been regulated. In fact in this law, it is precisely the formal sector work that is more prioritized in its regulation. As a result, arrangements for informal workers are still floating.

The focus of the study in this paper is the legal protection of women domestic workers in Indonesia. Currently there are several issues concerning legal protection for domestic workers, especially women who are often victims in terms of human resource exploitation and victims in violence that occurs within the scope of the household. The direction of legal politics towards the protection of women domestic workers in Indonesia is based on the philosophical foundation or ideal values contained in the second principle of the Pancasila "Just and Civilized Humanity". This value shows that every domestic worker without exception has the right to receive protection and fair treatment.

Data in May 2017 revealed by one of the Jala Coordinators of Domestic Workers (Domestic Workers' Union) showed that there were 129 cases such as unpaid wages, termination of employment before Eid and unpaid THR.

Data obtained from the Indonesian Ministry of Communication and Information (KOMINFO) website states that until 2019 there were 2,593,399 million Domestic Workers in Indonesia, with a total of 137,000 under the age of $18,72 \%$ of Domestic Workers were paid wages / salaries in under Rp. 300,000 per month. Meanwhile, of the total domestic workers in

Suteki and Ani Purwanti, "The Strategies of Women Protection In Solving Domestic Violencce Cases In Central Java Through Sheltered House,”Journal Diponegoro Law Review 01, No. 01 (2016): 115. 
Indonesia, 92\% were female workers and 42\% including Child Domestic Workers (PRTA) experienced psychological, physical and / or sexual violence. ${ }^{2}$

Of the 2,979 victims of sexual violence against women, there were 24 female domestic workers victims. The number of domestic workers in Indonesia is very high, both domestic workers, migrant and domestic stairs which are the main source of the family's economy poor. ILO 2009 estimates show a portion of Domestic Workers (PRT)is(90\%) women and children are working groups globally there are around 100 million in the world, of whom around 6 (six) million are migrant worker of households are from Indonesia while around 3 (three) million domestic workers. ${ }^{3}$ This shows that women domestic workers are also vulnerable to discriminatory actions from their employers. As regulated in Article 2 of Law No. 23 of 2004 concerning the Elimination of Domestic Violence explains that domestic workers are included in the scope of households, with the following arrangements: “(1) The scope of households in this Act include: (a) A husband, a wife, and children(s); (b) people who have a family relationship with the person as referred to in letter a because of blood, marriage, dairy, caring, and guardianship relationships, who reside in the household; and/or (c) people who work help the household and settle in the household; (2) People who work as referred to in letter c are considered as family members for a period of time while in the household concerned."

The reason of the division of public and private sphere influences the position private sphere is deemed as the maximum room for women, while the public is completely owned by men. Nevertheless, men also have complete power to private sphere. This thing makes women in the subordinated position from men. Since the position is subordinated to men, women seem more inferior than men. This inferiority has been imprinted in the society, supported by the legitimacy concerning philosophy, religious doctrine, and even positive law itself. ${ }^{4}$

This is the background of the need for protection of women domestic workers who are vulnerable to discriminatory treatment by employers. Therefore, in writing this paper, the author raises the title "Access to Justice for Legal Protection of Women Domestic Workers in Indonesia". The problems in writing this paper are as follows: 1) What is the urgency of legal protection for women domestic workers in Indonesia?; 2) What is the implementation of the

2 Kominfo, "Mari Penuhi Hak-Hak Pekerja Rumah Tangga," Accessed July 4, 2019 at 06.22 am.), https://kominfo.go.id/content/detail/5631/mari-penuhi-hak-hak-pekerja-rumah-tangga/0/infografis.

3 Wiwik Afifah, "Eksistensi Perlindungan Hukum Terhadap Pekerja Rumah Tangga Di Indonesia," DIH Journal Ilmu Hukum 14, No. 27 ( 2018): 54.

4 Ani Purwanti, "Protection And Rehabiitation For Women Victims of Violence According To Indonesian Law (Study On Central Java Government's Handling Through KPK2BGA)," Journal Diponegoro Law Review 02, No. 02 (2017): 313. 
protection of women domestic workers in Indonesia ?; and 3) What is the government's effort to optimize the legal protection for women domestic workers in Indonesia ?. The purpose of this paper is as follows: 1) To find out and analyze the urgency of the need for legal protection for women domestic workers in Indonesia; 2) To find out and understand the implementation of legal protection for women domestic workers in Indonesia; 3) To understand and analyze the government's efforts to optimize legal protection for domestic workers in Indonesia.

\section{Methods}

This writing uses a juridical-normative approach with analytical descriptions through literature study. Normative legal research places the norm system as the object of study. The norm system referred to as the object of study is all elements of legal norms that contain values about how humans should behave. This literature study uses secondary data consisting of primary legal materials, secondary legal materials, and tertiary legal materials.

The analytical descriptive nature means that the researcher Dalma explains the results of her research by describing the results of the study and the object of the study. In juridicalnormative research using a statutory approach, conceptual approach, and approach with case studies, as well as approaches with historical comparisons related to the object of research studies.

\section{Result and Discussion}

\subsection{Urgency of Legal Protection for Women Domestic Workers in Indonesia}

Achieving prosperity for the people of Indonesia is one of the goals of the Indonesian state. Efforts to create prosperity have been carried out in various ways by the government trying to meet the needs of the people of Indonesia, one of which is the fulfillment of needs in the field of employment, which is the main sector of society to depend on.

The regulation concerning the rights of citizens in obtaining work has been regulated in a juridical basis in Article 27 Paragraph (2) of the 1945 Constitution of the Republic of Indonesia which states that every citizen has the right to work and a decent living for humanity. In addition, it is also regulated in Article 28-D Paragraph (2) of the 1945 Constitution of the Republic of Indonesia which states that everyone has the right to work and to receive fair and appropriate compensation and treatment in an employment relationship. 
Then in Article 28-I Paragraphs (1 and 2) of the 1945 Constitution of the Republic of Indonesia also regulates the equality treatment of every citizen. The two articles govern as follows: (1) The right to life, the right not to be tortured, the right to freedom of thought and conscience, the right to religion, the right not to be enslaved, the right to be recognized as a person before the law, and the right not to be prosecuted on the basis of a law that applies ordered are rights human beings that cannot be reduced under any circumstances; (2) Every person has the right to be free from discriminatory treatment on any basis and has the right to get protection against such discriminatory treatment.

Women domestic workers have rights that must be fulfilled like other workers. As happened in some cases that many domestic workers, especially women who are marginalized or marginalized. Most people assume that women have a stereotype of working in an environment of "domestic jobs" (taking care of the household, cooking/washing, caring for children, gardening and other activities carried out around the house), while work outside of the home is done by men guys. This stereotype is based on understanding patriarchal cultural values that have been processed through socialization in community groups.

One of some reason from women to work as housemaid is their husband didn't work, that's why they worked as housmaid to improve their income. They also want to look for experience from the job but mostly they want to help economic condition in their household. ${ }^{5}$ In general, the mission / expectations to be achieved by the average female workforce in rural areas is an economic reason that is increasing family income. Whereas Novari, et al (1991) stated that working women certainly is not solely for reasons of family economic factors so difficult, but also some other motivations, like a husband not working / lacking income, want to find your own money, fill spare time, find experience, want to participate in the economy family and there is a desire to actualize themselves. ${ }^{6}$

This patriarchal culture which gave birth to the stigma that women have a lower position than men because there is a dominance of roles in the field of life by men. The portrait of Indonesian culture which is still patriarchal, is very not favoring the position of women victims of violence. Often women victims of violence are blamed (or partly blamed) for that violence perpetrators (male) carried out. For example, the wife of the victim of domestic violence by her husband blamed on the assumption that domestic violence was carried out by the victim's

\footnotetext{
5 Putu Martini Dewi, "Partisipasi Tenaga Kerja Perempuan dalam Meningkatkan Pendapatan Keluarga," Journal Ekonomi Kuantitatif Terapan 5, No. 2 (2012): 119.

6 Dwi Edi Wibowo, "Peran Ganda Perempuan dan Kesetaraan Gender,” Journal Muwazah 3, No. 01 (2011): 358.
} 
husband is the result of mistreating her husband. Stigma related victims the treatment (or service) to this husband has placed the victim as bad as the perpetrators themselves. ${ }^{7}$

Even so, female domestic workers who work at the employer's house are not included as women doing domestic work in the home because they have left their own sphere, so they are also categorized as workers as others who also have basic rights as workers according to Law No. 13 of 2003 concerning Manpower.

Protection of women domestic workers is also based on Article 5 and Article 6 of Law No. 13 of 2003 concerning Manpower which explains as follows: Article 5 : Every laborer/worker has the same of opportunity without discrimination to get a job.

Article 6: Every worker / laborer has the right to receive the same treatment without discrimination from the employer.

These two articles become a juridical basis in regulating the protection of every worker or labor. To understand labor and workers, Article 1 Number (2 and 3) of Law No. 13 of 2003 concerning Manpower explains the definition of workers and workers / laborers as follows: (2) Labor is every person who is able to do work to produce goods and / or services both to meet their own needs and for the community; whereas the definition of workers / laborers is regulated as follows (3) Workers / laborers are every person who works for a wage or other forms of remuneration.

Female domestic workers are part of workers / laborers who need legal protection as referred to in Article 4 of Law No. 13 of 2003 concerning Manpower explained that employment development aims: a) Empower and utilize the workforce optimally and humanely; b) Realizing equal employment opportunities and labor supply in accordance with national and regional development needs; c) Provide protection to workers in realizing welfare; and d) Improving the welfare of the workforce and their families.

Protection of women domestic workers is also based on the CEDAW Convention (Convention on the Elimination of All Forms of Discrimination Against Women) which has been ratified by Indonesia as a participating country of this convention, this is regulated in Article 3 of the CEDAW Convention which states that countries participating countries must take appropriate measures, including making laws and regulations in all fields, especially in the political, social, economic and cultural fields, to ensure the full development and progress of women, with the aim of ensuring that they exercise and enjoy their rights human rights and

7 Dede Kania, “The Rights of Women in Indonesian Laws and Regulations," Journal Konstitusi, No. 4 (2015): 720 . 
fundamental freedoms based on equality with men. Legal protection is important for Indonesia as a country called nomocracy or related to the rule of law, this concept was conveyed by Jimmly Asshiddiqie.

In the Minister of Manpower Regulation No. 2 of 2015 concerning Domestic Workers regulates the rights of domestic workers as described in article 7 as follows:

Domestic helpers have the right: (a) Obtain information about users; (b) Get good treatment from users and family members; (c) Get wages according to the Work Agreement; (d) Get healthy food and drinks; (e) Get enough rest; (f) Get leave rights in accordance with the agreement; (g) Getting the opportunity to do ibdah in accordance with the religion and beliefs professed; (h) Get holiday allowances; and (i) Communicate with his family.

Psychological problems experienced by some domestic workers include: a) unequal power relations by placing domestic workers in a subordinate position from their employers, b) underappreciation of the profession of domestic workers and the lack of wages given, c) the placement of domestic workers to be positioned as slavery and in absolute service and totality, and d) the remuneration provided to domestic workers is not balanced with the contribution that has been provided for their work services. ${ }^{8}$

\subsection{Implementation of Legal Protection for Women Domestic Workers in Indonesia}

The implementation of legal protection for women domestic workers in Indonesia has basically been regulated in the existing legislation in Indonesia including Law No. 13 of 2003 concerning Manpower and Regulation of the Minister of Manpower No. 2 of 2015 concerning Domestic Workers as implementing regulations.

Legal protection for domestic workers cannot be separated from a fair wage system. Understanding remuneration in a fair and professional manner must pay attention to the three aspects namely (technical, economic, and legal) in a comprehensive manner. ${ }^{9}$ Basically, domestic workers are part of the classification of unskilled laborers who have the designation of bluecollar workers using muscle power in their work, while other classifications mention the existence of professional workers or white-collar workers using brain power in their work. ${ }^{10}$

\footnotetext{
Retno Dwiyanti, "Analisis Kritis tentang Perlindungan Psikososial Pembantu Rumah Tangga," Jurnal PSYCCHO IDEA 7, No. 1 (2009): 6.

9 Abdul Khakim, Dasar-Dasar Hukum Ketenagakerjaan Indonesia (Bandung : Citra Aditya Bakti, 2009$), 1$.

10 Dedi Ismatullah, Hukum Ketenagakerjaan (Bandung : Pustaka Setia, 2013), 69.
} 
The implementation of legal protection for domestic workers in Indonesia is currently not optimal due to various problems of domestic workers in the field of wages and discriminatory treatment by their employers. The National Household Advocacy Helper Network in the News / Indonesia stated that from 2007 to 2011 there were 726 serious violence against domestic servants in Indonesia, consisting of 536 cases of unpaid wages, 348 of which occurred in domestic workers, 617 cases of detention, torture to severe injuries, and even to death. ${ }^{11}$

The sample that can be used as a case example is the case of Linawati (20), who died after being on Jalan Muara Karang, Blok J.X.U Number 73, Penjaringan, North Jakarta. The woman who works as (PRT) was killed at the hands of her own employer with LV alias V (51) years old. From witness statements, the victim was often treated harshly by the employer. The cause of death of the victim was almost five days the victim was not given food and locked in a bathroom until finally killed. The victim had not been given food for five days then was put in the bathroom and could not be removed, so that at 3:00 a.m. WIB the victim was found in a condition. The victim has also been tortured using an iron. The reason is trivial, if the victim's work is not neat in ironing clothes. ${ }^{12}$

Problems concerning domestic workers are often suffered by women or people who are vulnerable to discriminatory treatment. When seen from the Legal System Theory put forward by Lawrence M. Friedman which states that to form a good legal system, it requires 3 (three) components in it, including the component of the legal structure relating to the institution or its law enforcement apparatus, the related substance component with the norms contained therein, and the component of legal culture relating to the attitudes or willingness of the community to comply with existing rules and norms. ${ }^{13}$

This component of the legal culture serves as a benchmark for the awareness of users of "domestic workers" services to provide non-discriminatory treatment to domestic workers so that there is no more torture both violence and wages that do not meet the minimum standards for domestic workers. Users of domestic workers services should know what norms must be obeyed to ensure legal protection for women domestic workers.

\footnotetext{
11 Nur Hidayati, "Perlindungan terhadap Pembantu Rumah Tangga (PRT) Menurut Permenaker No. 2 Tahun 2015," Jurnal Pengembangan Humaniora 14, No. 3 (2014): 2.

12 Dwi Bowo Raharjo and Yosea Arga Pramudita, "Dikurung 5 Hari di Toilet dan Tak Diberi Makan, PRT Tewas Di tangan Majikan," Suara.com, Last modified May 21, 2019, Accessed July 10, 2019 at 7.44 pm.), https://www.suara.com/news/2019/05/21/163244/dikurung-5-hari-di-toilet-dan-tak-diberi-makan-prt-tewasditangan-majikan.

13 Esmi Warassih, Pranata Hukum (Semarang : Pustaka Magister, 2015), 24.
} 
The problems that arise regarding domestic workers who experience violence and inadequate wages are caused by the services of untrusted domestic workers. In Indonesia the recruitment of household help mostly occurs through friends and family. This is usually preferred because it offers a greater likelihood of finding a good employer and avoiding problems. Other recruitment channels can also be through informal intermediaries such as brokers or formal agents such as distributors. An untrusted channeling agent that creates vulnerability to discriminatory treatment of domestic workers. ${ }^{14}$

Legal protection for women domestic workers who still encounter many problems in Indonesia is influenced by several factors including female domestic workers who are vulnerable or marginalized so that the influence of patriarchal culture in Indonesia binds strongly to the problem of discriminatory actions against workers women's household. This problem can be related to the theory put forward by Soerjono Soekanto which explains that the factors affecting law enforcement include social and cultural factors. From the perspective of social and cultural systems, Indonesia is a plural society, there are ethnic groups with different cultures that result in different ways of solving problems between each structure of society. ${ }^{15}$

This shows that the protection of domestic workers in Indonesia still requires special attention from the government. Recalling that domestic workers are an occupation in the informal sector where the majority of workers are women. The special rights of women workers are regulated in Article 76 of Act No. 13 of 2003 concerning Manpower as follows: (1) Female workers / laborers under the age of 18 (eighteen) years are prohibited from being employed between 23:00 and 07:00; (2) Entrepreneurs are prohibited from employing pregnant women workers / laborers who, according to the doctor's statement, are hazardous to the health and safety of their wombs and themselves if they work between 23.00 and 07.00 WIB; (3) Entrepreneurs who employ female workers / laborers between 23:00 and 07:00 must: (a) Providing nutritious food and drinks; and (b) Maintain decency and safety while at work; (c) Employers are required to provide pick-up transportation for female workers / laborers who leave and return to work between 23:00 and 05.00 WIB.

This provision shows the efforts to protect the rights of women workers specifically by positive law in Indonesia. But even so, there are still discriminatory cases that result in female

${ }^{14}$ Maslihati Nur Hidayati, "Upaya Perlindungan Pekerja Rumah Tangga Sebagai Kelompok Masyarakat Yang Termarginalkan di Indonesia," Jurnal Al-Azhar Indonesia Seri Pranata Sosial 1, No. 1 (2011): 12.

15 Soerjono Soekanto, Faktor-Faktor yang Mempengaruhi Penegakan Hukum (Jakarta : Raja Grafindo Persada, 1983), 50. 
domestic workers feeling insecure. The violence and exploitation of housmaids were still occuring in Indonesia. Some cases have been processed by the law but the cases were still giving psycology pain for the victims. That's why to minimalize the cases of female housemaids violence, Indonesia should legitimize draft of protection domestic workers or housemaid Act. So that, it can prevent and give protection for Indonesian's housemaids especiallya Indonesian's female housemaids. ${ }^{16}$

As in the case of Maghfiroh (28 years) who was tortured by his employer in the Bintaro area, South Tangerang in mid-July 2018, the initial chronology of the persecution experienced by Maghfiroh began when Maghfiroh, the widow of two children, worked as a domestic servant in the EA family home. in the Bintaro housing complex, South Tangerang, was channeled from the Citra Kartini Foundation in Bintaro, because the employer was rude, he was not comfortable, and asked the foundation to pick him up. Because it never gets picked up, and Maghfiroh is asked by the foundation to stay in the house, Maghfiroh finally escapes from his employer's house in midJuly 2018. ${ }^{17}$

Therefore, entrepreneurs or companies or individuals who employ women are not as easy as imagined, there are things that must be considered including realizing that women have a weaker power by nature than men but have excess persistence in doing work, norms the norm in hiring women must uphold the norms of decency because women are vulnerable to negative things that threaten their lives especially when employed in amlam day, hiring women must also realize that they are still girls and some are married with a double burden among domestic work at home and outside work. ${ }^{18}$

Women who work in the public sphere even as domestic workers can also be categorized as having a double burden resulting in gender inequality so the best way to overcome the following is by giving more respect to women in terms of the production and reproduction sectors. ${ }^{19}$ Violence against women domestic workers is motivated by the culture of placing women under men who are influenced by strong religious doctrines in Indonesia so that some

16 Sri Tutatmiyah and Annalisa Y, "Pengakuan Hak-Hak Perempuan Sebagai Pekerja Rumah Tangga (Domestic Workers) Sebagai Bentuk Perlindungan Hukum Menurut Hukum Positif," Journal Dinamika Hukum 13, No. 01 (2013): 50.

17 Kirom, "PRT Bintaro Diseret, Dianiaya, Digunduli Karena Dituduh Mencuri oleh Majikannya" Merdeka.com, https://www.merdeka.com/peristiwa/prt-di-bintaro-diseret-dianiaya-digunduli-karena-dituduh-mencuri-oleh-eksmajikan.html (July 5, 2019 at 09.00 am.)

18 Zaeni Asyahdie, Hubungan Kerja Hukum Ketenagakerjaan Bidang Hubungan Kerja (Jakarta : Raja Grafindo Persada, 2015), 95.

19 Faqihuddin Abdul Kodir and Ummu Azizah Mukarnawati, Referensi bagi Hakim Peradilan Pidana tentang Kekerasan dalam Rumah Tangga (Jakarta : Komnas Perempuan, 2013), 13. 
people use religious arguments for their interests and class. Society has not been able to explore and interpret the meaning of politicization in religion on a massive scale. So there is a wrong view in the placement of women in the field of daily life including women as domestic workers. $^{20}$

\subsection{Government's Efforts in Optimizing Legal Protection for Women Domestic Workers in Indonesia}

One of the human resource development programs related to the field of employment states that there are activities to increase women's participation in the field of economic development, including supervision and protection of women workers. ${ }^{21}$ Government efforts to protect domestic workers have actually been regulated in Law No. 13 of 2003 concerning Manpower and Permenaker No. 2 of 2015 concerning Protection of Domestic Helpers. But in reality there is a need for good cooperation between the government and employers in carrying out existing regulations.

In the recruitment of workers, some companies still place women who are unequal to the position of men because of the conventional cultural view of society, namely the patriarchal view which places men as having more positions than women, even though the constitution clearly stipulates the equality between men men and women in Article 27 Paragraph (2) of the 1945 Constitution of the Republic of Indonesia. ${ }^{22}$

Manpower law enforcement especially in the informal sector still needs special attention so that there is a need for legal reform in the field of protection of domestic workers. The draft on the Domestic Workers Protection Bill actually exists but its ratification has not taken concrete action from the legislator. The Domestic Workers Bill provides arrangements that prioritize the rights of domestic workers. As the Domestic Workers Protection Bill clearly states the rights and obligations of domestic workers in articles 14 and 15 which explain as follows:

"Article 14: domestic servants are entitled to: (a) Living wages are decent; (b) Entitled to obtain information about the type of work to be carried out; (c) Holiday allowance for 1 (one) month salary; (d) Break times include weekly or yearly; (e) Additional knowledge / information and skills to increase work productivity ...”

\footnotetext{
20 Ristina Yudhanti, Perempuan dalam Pusaran Hukum (Yogyakarta : Thafa Media, 2014), 6.

21 Sulistyowati, Op.Cit., p. . 441.

22 Muntaha, "Perlindungan Hak Asasi Tenaga Kerja Wanita Lokal Pada Perusahaan Tambang di Kabupaten
} Konawe Utara," Jurnal Masalah-Masalah Hukum 46, No. 3 (2017): 229. 
"Article 15: Domestic helpers are obliged to: (a) Carry out the work properly and correctly according to the agreement and or work agreement; (b) Maintain decency and safety at work; (c) Maintain the good name and confidentiality of the family that is a personal service user and family; (d) Notify users of maid services if a maid will stop working for at least 15 (fifteen) calendar days; (e) Complete each job well; (f) Help to maintain the peace, tranquility and security of domestic helpers' homes."

In addition to the rights and obligations of domestic workers regulated in the draft Bill on the Protection of Domestic Workers, the rights and obligations of domestic workers users are also regulated in the draft Bill on articles 16 and 17 as follows:

"Article 16: Users of domestic servant services are entitled: (a) Obtain information about domestic workers; (b) Get skilled, loyal, and have a good work ethic; (c) Getting the work of domestic helpers in accordance with the agreement and / or work agreement.

Article 17: Users of domestic servant services are required to: (a) Pay wages according to agreements and / or work agreements; (b) Pay holiday allowance of 1 (one) month salary; (c) Allow time for rest; (d) Providing opportunities to practice worship according to religion and belief; (e) Provide occupational health and safety protection."

Domestic worker relations are informal relations in the labor field so that the basis is only based on trust. However, employment relationships that are only based on trust are inadequate to provide full protection to domestic servants both in legal and economic terms. The trust that is built in the working relationship between domestic servants and domestic servant service users is based on the Pancasila philosophy but this shows a problem on the ground so there is a need for effective means of preventing and overcoming high rates of violence against domestic workers. ${ }^{23}$

To realize an effective means, a legal basis is needed that is able to guarantee the fulfillment of the rights of domestic workers as well as the rights of users of domestic workers. So in optimizing the protection of women domestic workers the legalization of the Domestic Workers Protection Bill is required, because in this draft Bill also reflects respect for domestic workers who are mostly women. The Domestic Workers Protection Bill explains who is included as domestic workers.

Article 4 of the Domestic Workers Protection Bill explains the scope of domestic workers including: (1) The scope of work of domestic helpers includes work inside and outside the household; (2) Work in the household as referred to in paragraph (1) includes: a) domestic

23 Agusmidah, "Membangun Aturan Bagi Pekerja Rumah Tangga, Mewujudkan Hak Asasi Manusia," Jurnal Hukum Samudra Keadilan 12, No. 1 (2017): 2. 
workers (PRT); b) household management (PLRT); c) decrepit maid (caretaker); d) baby sitter (baby sitter); e) child guard (nanny); f) child care (governess); g) elderly servants (caregiver); (3) Work outside the household as referred to in paragraph (1), includes gardeners, private drivers, private security guards, and private teachers (recitation teachers).

To optimize the welfare of domestic workers, minimum wages are also needed. The purpose of this minimum wage is to highlight the meaning and role of workers in employment relationships, to protect groups of workers from the existence of a very low wage system, and to encourage the possibility of giving wages in accordance with the value of the work done. Insight concerns the terms and terms in remuneration, including: compensation, salary and wages; many definitions are given by scholars in various literatures. ${ }^{24}$

In ratifying the Domestic Workers Protection Bill, it must be based on the philosophical foundation of the Indonesian state, Pancasila. If liberalism emphasizes the teachings of individualism and Marxism, Pancasila places more emphasis on the ethics of Pancasila or moral philosophy in accordance with the teachings of Pancasila. ${ }^{25}$ Pancasilan moral teachings can be a guide line in every policy and regulation produced including regulations on the protection of women domestic workers in Indonesia.

Not only is the Domestic Workers Bill that can be used to deal with the problems of women domestic workers, but a referral service institution that can be used as a temporary place for domestic workers who feel themselves threatened from danger and have not gotten a place to stay for a while.

To provide repressive measures for women domestic workers who are victims, it can be referred to the Integrated Service Center for Women and Children Empowerment (P2TP2A) in order to obtain treatment in protecting victims from threats from various parties, especially the threat of physical violence. Therefore, at the central level a Task Force for Handling Women and Children (Satgas) was formed to assist the Community Complaints Section of the Ministry of Women's Empowerment and Child Protection and the Integrated Service Center for Empowering Women and Children in providing follow-up services to women and children with problems.. ${ }^{26}$

The Task Force was formed based on Ministerial Decree No. 25 of 2016 concerning the Task Force for the Handling of Problems of Women and Children at the Central Level while the

24 Moekiat, Administrasi Gaji dan Upah (Bandung : Mandar Maju, 1992), 1-5.

25 Sunoto, Mengenal Filsafat Pancasila, Pendekatan Melalui Etika Pancasila (Yogyakarta : Hanindita, 1985), 6-7.

26 https://kemenpppa.go.id/lib/uploads/slider/23bd2-sop-satgas-kpppa.pdf, On Wednesday July, 102019 at 7.00 pm. 
regional level is governed by the Governor / Regent / Mayor. The task force functions include: (a) Conducting outreach to women and children who experience problems; (b) Identifying the conditions and services needed by women and children who experience problems; (c) Protect women and children at the scene from things that could endanger themselves; (d) Placing and evacuating women and children who experience problems to the Integrated Service Center for Empowering Women and Children (P2TP2A) or other service institutions; and (e) Make referrals and / or recommendations to the nearest Integrated Women's and Children's Service Center or women's and children's service institutions to get further services. ${ }^{27}$

Each Integrated Service Center in each region has a referral service in the form of a safe house or temporary residence for victims of violence against women and children included in this case if victims of violence against women domestic workers who are threatened can be temporarily accommodated in the safe house. The understanding of safe houses is contained in every regional regulation governing the protection of women and children empowerment, such as the regulation of "safe house" referral services regulated in Regional Regulation of Central Java Province Number 3 of 2009 Concerning Implementation of Protection of Victims of Gender and Child Based Violence Article 1 Number (20) which states that a Safe House (shelter) is a temporary residence used to provide protection for victims in accordance with specified operational standards.

Handling for victims of violence against women domestic workers is one of the accesses of justice to provide legal protection for victims, especially women domestic workers who are often vulnerable to positions in community life and are considered to have a submarginal position compared to other communities working outside the sector.

\section{Conclusion and Recommendation}

\subsection{Conclusion}

From the discussion explained above, the following conclusions can be concluded: (1) The urgency for the protection of female domestic workers is motivated by a constitution that has established the existence of legal protection for each citizen to obtain decent work and livelihood

\footnotetext{
27 Bagian Pengaduan Masyarakat Biro Hukum Dan Humas Kementerian Pemberdayaan Perempuan Dan Perlindungan Anak, Prosedur Standar Operasional Satuan Tugas Penanganan Masalah Perempuan Dan Anak, (Jakarta: Bagian Pengaduan Masyarakat Biro Hukum Dan Humas Kementerian Pemberdayaan Perempuan Dan Perlindungan Anak, 2016), Accessed Wednesday July 10, $2019 \quad$ at $7.00 \quad$ pm.), https://kemenpppa.go.id/lib/uploads/slider/23bd2-sop-satgas-kpppa.pdf.
} 
as stipulated in Article 27 Paragraph (2) of the 1945 Constitution of the Republic of Indonesia 1945. In addition, Law No. 13 of 2003 concerning Manpower and Permenaker No. 2 of 2015 concerning Protection of Domestic Workers also regulates protection efforts for women domestic workers. Law No. 7 of 1984 concerning Ratification of the Convention Regarding the Elimination of All Acts of Discrimination against Women also provides protection for women domestic workers whose rights are oppressed. In addition, the increasingly high level of violence against domestic workers and the remuneration system that is still not yet accommodating the interests of domestic workers results in the need for optimization of protection for women domestic workers in Indonesia; (2) The implementation of legal protection for women domestic workers in Indonesia is considered to be still not optimal because there are still many cases regarding acts of violence against women domestic workers as well as wage systems that still do not meet standards in accordance with awards for the performance of domestic workers that are needed. Several cases show that there are still many violations of the rights of women domestic workers in Indonesia. As data from the National Network for Advocacy of domestic servants in the News / Indonesia states that from 2007 to 2011 there were 726 severe violence against domestic servants in Indonesia, consisting of 536 cases of unpaid wages, 348 of which occurred in domestic workers, 617 cases of detention, abuse to be seriously injured, and even to death; (3) The government seeks to optimize the protection of women domestic workers in Indonesia through positive law enforcement including enforcing the provisions contained in Law No. 13 of 2003 concerning Manpower and Permenaker No. 2 of 2015 concerning Protection of Domestic Workers. In addition to optimizing the protection for women domestic workers, the government is expected to be able to pass the Domestic Workers Protection Bill to accommodate the fulfillment of the rights of domestic workers, especially female workers who are marginalized and are in a subordinate position in the employment relationship with home service users stairs. This can minimize the occurrence of acts of violence or discriminatory acts against women domestic workers in Indonesia.

\subsection{Recommendation}

The problem regarding the protection of domestic workers is something that has been gradually occurring every year because basically the relationships that underlie domestic workers are only based on informal relationships that are only in the name of trust. Although the trust that is built is actually based on the philosophy of Pancasila, in reality, there are still many 
discriminatory actions against domestic workers, especially women who are considered to be subject to being easily marginalized by several factors including culture.

To optimize protection efforts for women domestic workers, the government should ratify the draft Domestic Workers Bill with legislators and that the draft bill be included in the National Legislation Program so there is priority in ratifying it.

\section{References}

Act Number 7 Year 1984 about CEDAW Ratification.

Act Number 13 Year 2003 about Employment.

Act Number 23 Year 2004 about The Eradication of Domestic Violence.

Affan, Heyde. "RUU Pekerja Rumah Tangga belum dibahas, PEMBANTU RUMAH TANGGA 'rentan diskriminasi." BBC Indonesia. Last modified June 16, 2017. Accessed Sunday, April 14, 2019 at 06.22 am. https://www.bbc.com/indonesia/indonesia-40284570

Agusmidah. "Membangun Aturan Bagi Pekerja Rumah Tangga, Mewujudkan Hak Asasi Manusia.” Jurnal Hukum Samudra Keadilan 12, No. 1 (2017).

Asshiddiqie, Jimmly. Konstitusi dan Konstitusionalisme Indonesia. Jakarta: Sinar Grafika, 2010. Asyahdie, Zaeni. Hubungan Kerja Hukum Ketenagakerjaan Bidang Hubungan Kerja. Jakarta: Raja Grafindo Persada, 2015.

Dewi, Putu Martini. "Partisipasi Tenaga Kerja Perempuan dalam Meningkatkan Pendapatan Keluarga.” Journal Ekonomi Kuantitatif Terapan 5, No. 2 (2012): 119.

"Draft Rancangan Undang-Undang tentang Perlindungan Pekerja Rumah Tangga." Accessed

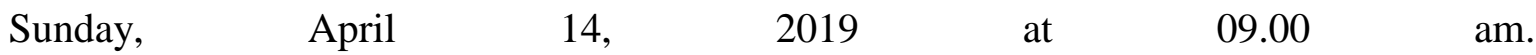
https://maskokilima.files.wordpress.com/2009/02/uu_prt_pdes_2008.pdf

Dwiyanti, Retno. “Analisis Kritis tentang Perlindungan Psikososial Pembantu Rumah Tangga.” Jurnal PSYCCHO IDEA 7, No. 1 (2009), ISSN 1693-1076.

Hidayati, Nur. "Perlindungan terhadap Pembantu Rumah Tangga (PRT) Menurut Permenaker No. 2 Tahun 2015.” Jurnal Pengembangan Humaniora 14, No. 3 (2014).

Irianto, Sulistyowati. Perempuan dan Hukum Menuju Hukum yang Berprespektif Kesetaraan dan Keadilan. Jakarta: Yayasan Obor, 2006.

Ismatullah, Dedi. Hukum Ketenagakerjaan. Bandung: Pustaka Setia, 2013.

Kania, Dede. "The Rights of Women in Indonesian Laws and Regulations." Journal Konstitusi, No. 4 (2015): 720. 
Khakim, Abdul. Dasar-Dasar Hukum Ketenagakerjaan Indonesia. Bandung: Citra Aditya Bakti, 2009.

Kirom. "PEMBANTU RUMAH TANGGA Bintaro Diseret, Dianiaya, Digunduli Karena Dituduh Mencuri oleh Majikannya” Merdeka.com. Accessed Friday, April 19, 2019 at 09.00 am. https://www.merdeka.com/peristiwa/prt-di-bintaro-diseret-dianiaya-digundulikarena-dituduh-mencuri-oleh-eks-majikan.html.

Kodir, Faqihuddin Abdul and Ummu Azizah Mukarnawati. Referensi bagi Hakim Peradilan Pidana tentang Kekerasan dalam Rumah Tangga. Jakarta: Komnas Perempuan, 2013.

Kominfo. "Mari Penuhi Hak-Hak Pekerja Rumah Tangga.” Accessed Sunday, April 14, 2019 at 06.22 am. https://kominfo.go.id/content/detail/5631/mari-penuhi-hak-hak-pekerja-rumahtangga/0/infografis

Komnas Perempuan. "Tergerusnya Ruang Aman Perempuan dalam Pusaran Politik Populisme, Lembar Fakta Catatan Tahunan Komnas Perempuan Tahun 2018.” Accessed Sunday, April 14, 2019 at 06.39 am. https://www.komnasperempuan.go.id/file/pdf_file/2018/SIARAN\%20PERS\%202018/Lem bar\%20Fakta\%20Catahu\%207\%20Maret\%202018.pdf

M. Hadjon, Philipus, et al. Pengantar Hukum Administrasi Indonesia. Yogyakarta: Gadjah Mada University Press, 2008.

Maslihati, Nur Hidayati. "Upaya Perlindungan Pekerja Rumah Tangga Sebagai Kelompok Masyarakat Yang Termarginalkan di Indonesia.” Journal Al-Azhar Indonesia Seri Pranata Sosial 1, No. 1 (2011): 12.

Minister of Employment Regulation Number 2 Year 2015 about Domestic Worker.Moekiat. Administrasi Gaji dan Upah. Bandung: Mandar Maju, 1992.

Muntaha. "Perlindungan Hak Asasi Tenaga Kerja Wanita Lokal Pada Perusahaan Tambang di Kabupaten Konawe Utara.” Jurnal Masalah-Masalah Hukum 46, No. 3 (2017).

Purwanti, Ani. "Protection And Rehabiitation For Women Victims of Violence According To Indonesian Law (Study On Central Java Government's Handling Through KPK2BGA).” Journal Diponegoro Law Review 02, No. 02 (2017): 313.

Sunoto. Mengenal Filsafat Pancasila, Pendekatan Melalui Etika Pancasila. Yogyakarta: Hanindita, 1985. 
Suteki and Ani Purwanti "The Strategies of Women Protection In Solving Domestic Violencce Cases In Central Java Through Sheltered House.” Journal Diponegoro Law Review 01, No. 01 (2016): 115.

The Constitution of The Republic of Indonesia in 1945 (UUD NRI Tahun 1945).

Tutatmiyah, Sri and Annalisa Y. "Pengakuan Hak-Hak Perempuan Sebagai Pekerja Rumah Tangga (Domestic Workers) Sebagai Bentuk Perlindungan Hukum Menurut Hukum Positif.” Journal Dinamika Hukum 13, No. 01 (2013): 50.

Wibowo, Dwi Edi. "Peran Ganda Perempuan dan Kesetaraan Gender.” Journal Muwazah 3, No. 01 (2011): 358.

Yudhanti, Ristina. Perempuan dalam Pusaran Hukum. Yogyakarta: Thafa Media, 2014. 